\title{
„Stworzenie czlowieka” i typy komunikowania. Studium hermeneutyczne
}

Problem typologii komunikowania nie należy do zagadnień, żywo inte-
resujących teoretyków komunikacji masowej. Najszerszą z obecnych w polskim obiegu naukowym klasyfikacją wydaje się zaproponowana przez McQuaila i przytaczana w całości m.in. przez Tomasza Goban-Kla$\mathrm{sa}^{1}$ piramida, ukazująca poziomy komunikacji, wyodrębnione wedle kryterium ilościowego: zależnie od tego, ile osób uczestniczy w procesie komunikacji - jedna, dwie, kilka czy dużo - wyróżnia się komunikowanie intrapersonalne, czyli wewnątrzosobowe, interpersonalne, grupowe, instytucjonalne oraz komunikowanie masowe. Jednak ,poziomów” nie sposób utożsamiać z typami - różnice ilościowe nie mogą konstytuować typu. Można wprawdzie domniemywać, że pomiędzy wyróżnionymi poziomami komunikowania są również jakieś różnice istotne, różnice jakościowe, nie one jednak stanowią podstawę tej klasyfikacji.

W polskojęzycznej literaturze kwestia typologii relacji komunikacyjnych nie jest łączona z problemem definicji samej komunikacji ${ }^{2}$. Wynika to prawdopodobnie $\mathrm{z}$ opisowego podejścia do kwestii definicji. $\mathrm{W}$ jed-

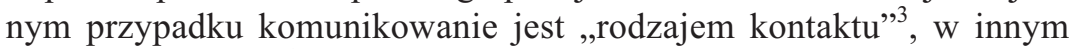
- „mechanizmem”, w jeszcze innym - „zachowaniem”, czy „formą

1 Zob. T. Goban-Klas, Media i komunikowanie masowe. Teorie i analizy prasy, radia, telewizji $i$ Internetu, Warszawa-Kraków 2002, s. 32.

2 Chociaż czasem potrzeba takiego łączenia zostaje mimo woli ujawniona. Zob. M. Mrozowski, Władza, rozrywka i biznes, Warszawa 2001, s. 14.

3 Zob. Ibidem.

4 Zob. T. Goban-Klas, Media i komunikowanie..., op. cit., s. 45.

5 Zob. M. Kunczik, A. Zipfel, Wprowadzenie do nauki o dziennikarstwie i komunikowaniu, Warszawa 2000, s. 13. Gwoli sprawiedliwości trzeba odnotować, że choć ostatecznie autorzy decydują się na „,zachowanie”, niejako „po drodze” definiują również komunikację jako ,interakcję dokonującą się przy użyciu symboli”, co, w przeciwieństwie do ,zachowania”, terminu prowadzącego nieuchronnie do redukcjonizmu, otwiera pewne perspektywy teoretyczne. 
działania"6. Wprawdzie autor definicji, w której ten ostatni termin pełni rolę orzecznika, dobitnie podkreśla konieczność ujmowania komunikacji w kontekście władzy, ale teleologiczny paradygmat, przyjęty przezeń przy definiowaniu władzy, również utrudnia podjęcie kwestii podziału na typy ${ }^{7}$. Pewien punkt wyjścia do budowania typologii mogłoby stanowić porządkowanie występujących w literaturze definicji. T. Goban-Klas wymienia w tym kontekście m.in. komunikowanie pojęte jako transmisja, jako rozumienie, jako oddziaływanie, jako wymiana czy jako interakcja, ostatecznie jednak zgłasza wobec analizy definicji komunikowania swoje desinteressement ${ }^{8}$. W efekcie więc to dzielenie komunikacji na bezpośrednią (interpersonalną) i zmediatyzowaną (masową) okazuje się najbardziej rozpowszechnionym w nauce o komunikowaniu (obok podziału na komunikację werbalną i niewerbalną) sposobem podziału relacji komunikacyjnych $^{9}$. Typologia ta nasuwa przypuszczenie, że jej źródłem nie jest jakaś ogólna teoria komunikowania, ani tym bardziej filozofia, lecz „nauka o komunikowaniu masowym; świadczy o tym akcent na istnienie lub brak instytucji pośredniczącej w procesie komunikacji ${ }^{10}$ - zaś wyodrębnienie, obok zapośredniczonej, masowej komunikacji, również komunikacji interpersonalnej, nie wymagającej żadnego pośrednictwa (komunikacji

${ }^{6}$ Zob. J. B. Thompson, Media i nowoczesność. Spoteczna teoria mediów, Wrocław 2001, s. 21.

Zob. ibidem. Samą władzę dzieli autor w gruncie rzeczy wedle rodzajów, a nie wedle typów, gdy wymienia władzę gospodarczą, polityczną czy symboliczną. Właśnie wspomniany teleologizm jest tu przeszkodą na drodze do wyodrębnienia typów.

${ }^{8}$ Zob. T. Goban-Klas, Media i komunikowanie..., op. cit., s. 42.

9 Zob. M. Mrozowski, Wtadza, rozrywka i biznes..., op. cit., s. 31, gdzie autor z piramidy McQuaila zachowuje jeszcze komunikowanie instytucjonalne. Należy podkreślić, że Mrozowski zamiennie stosuje wobec „poziomów” również pojęcie „typów”. Ale pomimo iż komunikacja interpersonalna wyodrębniona jest expressis verbis jako typ i w dodatku jako typ wiodący (,,pokrywa się w istocie z ogólnym modelem komunikowania”), a w dodatku przypisana jej została ważna cecha „wzajemności”, to ostatecznie to, co dla niej najbardziej charakterystyczne, uznane zostało za coś marginalnego, bo „komunikowanie jest działaniem celowym i racjonalnym”; ponadto wprawdzie „proces komunikowania może być [ale tylko może być - R.P.] dwukierunkowy”, za to „każdy akt komunikowania ma jednokierunkowy charakter”.

10 Nie zawsze mamy do czynienia z ostrym przeciwstawieniem komunikacji interpersonalnej jako bezpośredniej i masowej jako zmediatyzowanej. Tak np. M. Mrozowski, który wprawdzie, jak sam pisze, nie pretenduje do stworzenia definicji, ale jednak definicję podaje, mówi o zrozumiałych dla stron znakach, za pomocą których przekazywane są ,pewne treści pojęciowe”. Zob. M. Mrozowski, Media masowe..., op. cit., s. 14 . 
face to face) wygląda na motywowane potrzebą umieszczenia nauki o komunikowaniu masowym w prestiżowym szerszym kontekście ogólniejszej teorii. Nie znaczy to oczywiście, że podział komunikacji na masową i interpersonalną jest pozbawiony wartości eksplanacyjnej; przeciwnie, już na pierwszy rzut oka widać, że różnice między nimi upoważniają do radykalnego ich przeciwstawienia. Jednakże uznanie komunikacji interpersonalnej za niezapośredniczoną - niezapośredniczoną w ogóle, a nie tylko przez „mass media” - wydaje się co najmniej pochopne: komunikacja interpersonalna jest bowiem tylko w wąskim sensie nie zapośredniczona. Komunikacja interpersonalna, jako nie masowa właśnie, nie wymaga zapośredniczenia przez środki, nadające komunikatom masowy zasięg, nie jest jednak ,bezpośrednia” w tym znaczeniu, by się mogła obyć bez jakichkolwiek „mediów” - bez języka, bez instytucji organizujących - również w skali indywidualnej - społeczny proces komunikowania, by mogła się obyć bez kultury jako uniwersalnego medium komunikacji ${ }^{11}$. W tym ogólnym sensie (pomimo innych różnic między komunikacją interpersonalną i masową) nie istnieje coś takiego jak komunikacja niezmediatyzowana. Jest wprawdzie jeden wyjątek, ale też ta wyjątkowa komunikacja nie jest ani masowa, ani interpersonalna w zwykłym rozumieniu tego pojęcia, chociaż co najmniej jedna z uczestniczących w niej stron jest czymś w rodzaju ,persony”. Ale tylko czymś w rodzaju, bowiem dopiero w procesie tej szczególnej komunikacji, o której tu mowa, owa strona może się stać kimś; można tego kogoś nazwać osobą, chociaż z pewnych względów nie jest to określenie najszczę́liwsze ${ }^{12}$. Ten rodzaj komunikacji, jako dokonujący się poza kulturą, a więc w sferze transcendencji, w sferze, w której wytwarzane są wartości podstawowe, przebiega w obrębie doświadczenia metafizycznego, a więc fundamentalnego, kulturowo nie zapośredniczo-

11 Zob. szerzej R. Paradowski, Modele komunikacji, pluralizm etyczny i typy dziennikarstwa, „Przegląd Politologiczny” 2005, nr 2.

12 Nie chodzi tu o potoczne rozumienie „osoby”, lecz o jej rozumienie związane z kontekstem ideologicznym, a konkretnie - z kontekstem, dostarczanym temu pojęciu przez doktrynę chrześcijańską, pozbawiającą, ,osobę” istotnych kompetencji metafizycznych. Zresztą nawet Kant (w każdym razie we Wprowadzeniu do metafizyki moralności, Warszawa 2005, s. 31) wprawdzie uważa, że osoba jest podmiotem, ale tylko takim, któremu ,przypisać można dokonane przezeń czyny...”, co jeszcze samo przez się nie oznacza żadnej określonej kompetencji metafizycznej; nieco dalej jednak stwierdza, że „dana osoba nie może podlegać żadnym innym prawom za w y jąt kiem tych, które sama dla siebie ustanowiła (samodzielnie bądź wespół z innymi) [podkr. R.P.]". 
nego wyodrębnienia się i odróżnienia ,ja” od tego, co nim nie jest, od „nie-ja”,13. Komunikacją jest w tym procesie wymiana komunikatów o podejmowanych przez ,ja” i „nie-ja” wyborach metafizycznych, dotyczących obu stron tej szczególnej „relacji komunikacyjnej”, a więc i samej tej relacji. Wyborach, które konstruują tożsamość owych stron i charakter relacji między nimi, strony przetwarzają w wartości (podmioty względnie przedmioty), a samą relację czynią „wartościową"14. Komunikacja interpersonalna, o ile zawiera w sobie ten aspekt metafizyczny (a żadna, jak się wydaje, nie jest go pozbawiona), jest kulturowo nie zapośredniczona, ale też tylko w tym (metafizycznym) aspekcie. Pod każdym innym względem (przede wszystkim pod względem swej podstawowej funkcji, jaką jest wywoływanie pożądanego zachowania odbiorcy komunikatu w kwestiach wykraczających poza treść komunikatu metafizycznego ${ }^{15}$ ) jest to komunikacja zapośredniczona przez wspomniane wyżej formy kulturowe $^{16}$. Reasumując, podział komunikacji na interpersonalną i masową jest co najmniej nieostry, jakkolwiek, z uwagi na metafizyczny aspekt,

${ }^{13}$ Na temat pewnej propozycji filozoficznego rozumienia transcendencji zob. szerzej W. Paradowska, R. Paradowski, Podmiotowość jako transcendencja. Przyczynek do problemu podmiotowości politycznej, „Środkowoeuropejskie Studia Polityczne” 2005, $\mathrm{nr} 1$.

${ }^{14}$ Powyższe trzeba uściślić w aspekcie opozycji „,bezpośrednia-zmediatyzowana": nawet ta dokonująca się w transcendencji, a więc poza systemem kulturowych determinacji, komunikacja, jest tylko kulturowo nie zmediatyzowana, nie jest jednak całkowicie wolna od jakiejkolwiek „mediatyzacji”, a więc i determinacji, chociaż nie jest to mediatyzacja w pełnym tego słowa znaczeniu: czymś quasipośredniczącym w wyborach metafizycznych i ich komunikowaniu przez ,ja” sobie i „nie-ja” (ale także przez „nie-ja” sobie i mnie) jest metafizyczne doświadczenie, czyniące metafizyczne wybory koniecznymi, chociaż wolnymi co do treści. Więcej nawet: kulturowo nie zapośredniczony jest tylko wybór metafizyczny, ale już przekaz jego treści wykorzystuje w sposób konieczny kulturowe formy komunikacji. W sprawie doświadczenia metafizycznego i metafizycznych wyborów oraz budowanych na ich podstawie porząqdków kulturowych zob. W. Paradowska, R. Paradowski, Typology of cultures and economy in culture, „Hemispheres. Studies on Cultures and Societies” 2003, nr 18.

15 Daj się traktować jak przedmiot mojego panowania, traktuj mnie jak przedmiot swojego panowania, daj się traktować jak podmiot, a więc zarazem jak ktoś uznający moją podmiotowość. Nawiasem mówiąc, ,pożądane zachowanie” jest kategorią, odnoszącą się również do sfery metafizycznej: w y m a g a m y poddania, wymagamy opieki, wymagamy wreszcie równego traktowania.

${ }^{16}$ W sprawie typologii mediów kultury zob. R. Paradowski, Modele komunikacji..., op. cit. 
kryjący się w pierwszej z nich ${ }^{17}$, nie pozbawiony heurystycznego potencjału. W szczególności dosyć rozwinięte w ramach interpersonalnej komunikacji sprzężenie zwrotne (na co zwraca się czasem uwagę ${ }^{18}$ ) może sugerować pewien sposób podziału sytuacji komunikacyjnych, wymagało by to jednak $\mathrm{z}$ kolei rezygnacji $\mathrm{z}$ traktowania komunikacji masowej wyłącznie jako transmisji ${ }^{19}$; tak czy inaczej wymaga to uznania za podstawowy jakiegoś innego podziału, niż narzucony przez naukę o komunikowaniu masowym podział na komunikowanie interpersonalne i masowe. Najwyraźniej bowiem zarówno interpersonalne, jak i masowe komunikowanie nie jest „niepodzielne” (nawet oba razem nie stanowią ,atomów” komunikacji), za to wyodrębnienie komunikatu jako „cząstki elementarnej” ma prawdopodobnie tylko uzasadnienie analityczne - „komunikat”, rozumiany jako przekaz treści od nadawcy do odbiorcy (a więc jako jednokierunkowy), nie ma samodzielnego statusu ontycznego ${ }^{20}$.

Czy jednak interpersonalna komunikacja może od masowej różnić się tylko ilościowo, a więc tylko pod względem ilości uczestników sytuacji komunikacyjnej? Jest to, empirycznie rzecz biorąc, jedyna różnica, po wykazaniu, iż wąsko rozumiane media nie mogą stanowić wystarcza-

17 Aspekt metafizyczny obecny jest w każdej relacji komunikacyjnej, a więc zarówno w masowej, jak i interpersonalnej, z tym, że tylko w tej drugiej w postaci wyboru metafizycznego, podczas gdy w pierwszej z nich w kulturowych formach wartości.

18 Zob. np. W. P. Konieckaja, Socyołogija kommunikacyi, Moskwa 1997, s. 179 i n.

19 Jak czyni to np. T. Goban-Klas: „Sprzężenie zwrotne... nie oznacza dwukierunkowego komunikowania. ...założenie dwukierunkowości transmisji zakłada w istocie dwa odrębne akty komunikowania...". Media i komunikowanie masowe. Teorie i analizy prasy, radia, telewizji i internetu, Warszawa-Kraków 1999, s. 45. Z drugiej strony autor ten nie odcina się od szerokiego definiowania komunikacji w kontekście kultury (zob. s. 46), co w połączeniu ze skłonnością do redukowania komunikacji do transmisji musi rzutować na specyficzny (redukcjonistyczny) sposób pojmowania kultury. Jeśli „,kultura jest komunikowaniem” (Hall), a struktura komunikowania to nadawca - (medium) - odbiorca, to taka też musi być struktura każdej kultury. Jednokierunkowego co do istoty charakteru komunikowania broni M. Mrozowski, który w ,procesie komunikowania” dopuszcza wprawdzie możliwość dwukierunkowości (,proces komunikowania może być jednokierunkowy bądź dwukierunkowy"), natomiast to, co elementarne (,akt komunikowania”) redukuje jednoznacznie, jak już wspominałem, do transmisji (,„każdy akt komunikowania ma jednokierunkowy charakter”). Zob. jego Media masowe..., op. cit., s. 29.

${ }^{20}$ Inaczej T. Goban-Klas: „...nieuprawnione jest określanie wszelkiej reakcji odbiorcy mianem komunikatu”. Ibidem, s. 44. Oznacza to ni mniej ni więcej, że „reakcja” jest tylko „,behawiorem”, zaś podmiotowość przysługuje jedynie nadawcy. Autorytarne konsekwencje takiego stanowiska wydają się oczywiste. 
jącego kryterium różnicującego, zaś media rozumiane szeroko obu tych „typów” nie różnicują. Czy nie może być tak, że komunikacja interpersonalna i komunikacja masowa mogą przynależeć do różnych ogólniejszych typów, ale mogą też przynależeć do tego samego? Inaczej mówiąc, czy nie należałoby wskazać na jakieś istotniejsze, niż tylko ilościowe, kryterium podziału sytuacji komunikacyjnych? Ale dla sięgnięcia do tego, co istotne, należałoby wyjść poza empiryczne konstatacje (do takiej konstatacji sprowadza się w gruncie rzeczy podział komunikacji na interpersonalną i masowa) ku analizie przekazu kulturowego i filozofii.

Istnieje wiele przekazów kulturowych, które mogą ilustrować będącą przedmiotem poniższych rozważań podstawową klasyfikację sytuacji komunikacyjnych. Mity jako nośnik archetypów podstawowych relacji międzyludzkich istnieją w różnych kulturach i zawarte są w najważniejszych dla tych kultur tekstach. Zważywszy na to, że cel niniejszego artykułu jest raczej koncepcyjny niż opisowy, ograniczę się do jednej tylko ilustracji kulturowej, pomijając zupełnie przykłady, które można by zaczerpnąć z innych kultur. Jednym z najważniejszych tekstów kultury europejskiej jest ,święte pismo”, znane między innymi pod nazwą „Starego Testamentu", z niego więc zaczerpnięte zostaną przekazy mityczne, które oprócz wszystkiego innego, co w sobie zawieraja, ukazują dwa podstawowe typy komunikacji, dwie podstawowe sytuacje komunikacyjne. Kulturowy komunikat o komunikowaniu zawarty jest przede wszystkim w opowieściach o stworzeniu człowieka.

Zanim jeszcze dwie podstawowe sytuacje komunikacyjne zostana z mitu o stworzeniu człowieka wydobyte, warto zauważyć, że wysiłek, mający na celu przedstawienie w kategoriach komunikacji również tego, co „na początku”, jest w opisie tego, co na początku, dość dobrze widoczny. I jest to rzeczywiście „wysiłek” w tym znaczeniu, że brak jeszcze kategorii, którymi „rzeczywistość” można by opisać - bo sama ta rzeczywistość (jako par excellence rzeczywistość komunikacyjna) jest jeszcze in statu nascendi. Żeby dokonać jej oglądu, zaprezentować ją, a może nawet stworzyć (stworzyć świat!), trzeba najpierw ukazać stworzenie człowieka. Więcej nawet: trzeba najpierw człowieka stworzyć. Zajmijmy się więc stworzeniem człowieka - zobaczymy wtedy, że wszystko to, co ,przedtem”, ma jedynie status literackiej narracji: n i e moż e is t n i éc przed „stworzeniem człowieka”. A jeśli nawet, to owo istnienie może mieć co najwyżej status wyobrażony.

Bóg Starego Testamentu stwarza człowieka dwa razy, albo inaczej - mamy w Starym Testamencie dwie opowieści o stworzeniu człowieka. 
To konstrukcyjne dziwactwo tłumaczy się zwykle kompilatorskim charakterem dzieła, a więc połączeniem w jedną całość literacką opowieści pochodzących od ,jahwisty” i opowieści pochodzących od „elohwisty”. To by sugerowało, że „redaktorom” szkoda było zostawić w historycznej i kulturowej niepamięci któryś z pomników kultury, gdyby, kierując się własnym gustem, jeden z nich tylko zostawili w tekście, drugi zaś pominęli. Wydaje się jednak, że tłumaczenie to nie wytrzymuje konfrontacji z samym tekstem: wygląda na to, że oba opowiadania są konieczne, dopiero oba bowiem zawierają w sobie całość kulturowego komunikatu. A dokładniej: całość kulturowego komunikatu zawiera się w obu opowiadaniach o stworzeniu człowieka, uzupełnionych o opowiadanie o zerwaniu owocu. Przy czym opowiadanie o zerwaniu owocu, będące w różnych swoich częściach uzupełnieniem obu opowiadań o stworzeniu człowieka, jest w ostatecznym efekcie dopełnieniem - merytorycznym dopełnieniem - przede wszystkim opowiadania pierwszego. Tego, w którym mówi się o stworzeniu mężczyzny i kobiety „na obraz i podobieństwo Boga”21.

O koniecznym charakterze obu opowiadań (o tym, że żadne z nich nie mogłoby być w tekście pominięte), świadczy różnica między nimi. Jednak nie ta, związana na przykład z tym, że w jednym opowiadaniu mówi się o materiale, z jakiego stworzony został człowiek (że został mianowicie stworzony z ,prochu ziemi”), w drugim zaś kwestia materiału jest zupełnie pominięta, albo na przykład z tym, że jedno jest skrajnie lapidarne, drugie zaś bardzo rozbudowane. Ale już fakt, że w jednym mówi się o stworzeniu człowieka na obraz i podobieństwo Boga, w drugim zaś to odniesienie zupełnie się pomija, jest bardziej znaczący. Najbardziej jednak znaczącą różnicą jest to, że w drugim opowiadaniu jako człowieka Bóg stwarza jedynie mężczyznę (któremu potem kobieta jedynie zostaje przydana do pomocy), podczas gdy w pierwszym kobietę i mężczyznę stwarza jednocześnie, w żaden sposób nie sugerując ich nierównego statusu, więcej nawet - podkreślając $c^{22}$, że oboje razem są „obrazem Boga”, a więc, że stanowią względem siebie wartości równorzędne ${ }^{23}$. Równo-

21 Z antropologicznego punktu widzenia opowiadanie o zerwaniu owocu jest ostatecznie uzupełnieniem obu opowiadań o stworzeniu, dopiero bowiem te trzy opowiadania łącznie dają obraz przebiegu i efektu antropogenezy.

22 Ściśle rzecz biorąc to narrator podkreśla. Nawiasem mówiąc, w tak krótkim tekście dwukrotne odwołanie do „obrazu Boga” nie może być przypadkowe.

23 Gdyby ktoś chciał twierdzić (zresztą całkowicie wbrew związanej z drugim opowiadaniem obowiązującej interpretacji relacji między mężczyzna i kobietą), że nie 
rzędność tę podkreśla skierowany do obojga apel o zaludnianie ziemi i czynienie jej sobie poddaną ${ }^{24}$. Jednak jeszcze bardziej charakter relacji między mężczyzną i kobietą, zaznaczony w pierwszym opowiadaniu, wydobyty jest przez różnicę: w drugim opowiadaniu relacja ta zostaje drastycznie zmieniona na relację hierarchiczną, a mężczyzna i kobieta przestają być wartościami równorzędnymi. Po pierwsze, inaczej niż w opowiadaniu pierwszym, gdzie człowiek jako obraz Boga, a więc właściwie z Bogiem tożsamy, nie może być mu, ex definitione, poddany, w opowiadaniu drugim jest mężczyzna od razu Bogu podporządkowany. Wprawdzie najpierw Bóg się mężczyzną, zwanym tu człowiekiem, zaopiekował („umieścił go w ogrodzie Eden”25), co zresztą, jak wiadomo, nie tylko nie kłóci się z relacją władzy, ale raczej stanowi jej immanentny składnik; przede wszystkim jednak ustanowił między nim i sobą relację hierarchiczną: zastrzegł dla siebie to co najważniejsze - wyłączne prawo definiowania tego co dobre i tego co złe, tym samym go sobie podporządkowując. Z a k o m u n i k o w a $\nmid$ mu swoją wolę. Domyślamy się, że mężczyzna milcząco przyjął ją dowiadomości. Aby dać wyraz trosce o poddanego, Bóg postanowił rozproszyć samotność mężczyzny, mówiąc do wyobrażonego odbiorcy komunikatu (podobnie jak wtedy, gdy mówił „Niech się stanie światłość”26): ,...uczynię mu zatem odpowiednią dla niego pomoc"27. Różnica jest jednak zasadnicza: tam nie było jeszcze rozwiniętej sytuacji komunikacyjnej (nie było interlokutora), trzeba więc ją było sobie imaginować, stwarzając jej wyobrażeniowy substytut. Tu zdawać by się mogło, że wszystkie niezbędne elementy komunikacji zostały stworzone; przede wszystkim stworzony został człowiek jako strona relacji komunikacyjnej. Został stworzony, ale pierwszym komunikatem $\left(, \ldots\right.$. z drzewa poznania dobra i zła nie wolno ci jeść $\left.{ }^{28}\right)$,ustawiony" został jedynie jako odbiorca.

oznacza to tym samym, że są równi Bogu, odpowiemy, że w pewnym sensie „są” Bogiem, skoro są jego obrazem; są więc nie tyle równi Bogu, co tożsami z nim (ale, co charakterystyczne), tylko według tego opowiadania.

24 Często to, czego nie ma, jest nie mniej znaczące od tego, co jest: Bóg nie nakazuje ludziom, by czynili ziemię jemu poddaną, lecz by czynili ja poddaną s o b i e.

$25 \mathrm{Rdz} 2,15$,....aby uprawiał go i doglądał”, a więc praca nie pojawiła się dopiero wraz z ,upadkiem”. To tylko na marginesie, nie jest bowiem moim zamiarem wydobywanie sprzeczności w tekście, co najwyżej w jego oficjalnej interpretacji.

$26 \mathrm{Rdz} 1,3$.

$27 \mathrm{Rdz} 2,18$.

$28 \mathrm{Rdz} 2,17$. 
Jako ,pomoc” dla mężczyzny stworzone zostały najpierw zwierzęta, co, z wiadomych względów, nie do końca go usatysfakcjonowało. Dopiero wtedy Bóg (Bóg z drugiej opowieści!) stworzył mężczyźnie „do pomocy" kobietę, ustanawiając tym samym najniższy (nie licząc zwierząt) szczebel hierarchii. Nic jej specjalnie nie komunikował, uznając (zgodnie z logiką hierarchii), że to nie do niego należy.

Same w sobie obie te opowieści nie dają nam jeszcze pełnego obrazu sytuacji komunikacyjnych (chociaż druga opowieść zawiera już ważne elementy całości), nie taki jest bowiem ich zasadniczy cel. Tym celem jest mianowicie ukazanie dwóch archetypów, dwóch obrazów człowieka: jako złożonego z równych sobie nawzajem kobiety i mężczyzny i jako nierównych, włączonych jako różne szczeble do rozbudowanej „hierarchii stworzenia”. Wszelako, jak wspomniałem, opowiadanie drugie daje nam wgląd w jakąś specyficzną sytuację komunikacyjną. Domyślamy się, że musi ona być specyficzna, bo jej przesłanki (stworzone zresztą samym komunikatem), są zupełnie inne, niż przesłanki, jakie dla możliwej sytuacji komunikacyjnej stwarza opowiadanie pierwsze. Wprawdzie i tam Bóg ludziom coś komunikuje („błogosławi” ich, zachęca do seksu i do pracy), po pierwsze jednak ma to raczej charakter apelu niż rozkazu (komunikatami tymi nie ustanawia Bóg swojej władzy nad nimi), po drugie im samym nie sugeruje wzajemnie nierównego traktowania, i po trzecie (i najważniejsze) - sam on wydaje się być tu raczej figurą stylistyczną, raczej „obrazem Boga”, raczej synonimem całości, na którą składają się mężczyzna i kobieta, niż spersonifikowaną władzą (podmiotem nadrzędnym). Dlatego jego apel jest raczej quasikomunikatem, a relacja z ludźmi jest quasirelacją komunikacyjną. Ciągle więc mamy tylko elementy całości komunikacyjnej (quasinadawcę mówiącego do siebie np. „Niech powstanie sklepienie...",29, pozbawiony nadawcy quasikomunikat ${ }^{30}$, a przede wszystkim nie będącego odbiorcą nadawcę komunikatu i nie będącego nadawcą jego odbiorcę ${ }^{31}$, i oczywiście pełnowymiarowy komunikat ${ }^{32}$. Wszystko to jednak nie składa się jeszcze na całość, nie wyczerpuje możliwych typów sytuacji komunikacyjnych. Całościowy obraz komunikacji uzyskujemy dzięki opowiadaniu,

\footnotetext{
$29 \mathrm{Rdz} 1,6$.

30 Zob. Rdz 1,28-29.

31 Zob. Rdz 2,16-17.

32 Zob. ibidem.
} 
przewrotnie przez oficjalną, polityczną interpretację określonemu jako „upadek pierwszych ludzi" ${ }^{33}$.

Opowiadanie o ,upadku” jeszcze raz potwierdza literacki par excellence (i szerzej - kulturowy) charakter Księgi. Ciagle nie mamy jeszcze s y s t e m u komunikacji (nie został jeszcze przedstawiony kompletny zestaw typowych sytuacji komunikacyjnych), mamy natomiast następną for $\mathrm{m} \mathrm{e}^{34}$ komunikacji, która jako taka zinterpretowana być może dopiero w świetle teorii typów: dialog wewnętrzny. Głos wewnętrzny, drugie „ja” - to kategorie, które pojawiają się już na początku tego opowiadania. Kobieta rozmawia sama z sobą, wiemy jednak, że dodatkowy głos wewnętrzny to zinterioryzowany wyobrażony rozmówca. Być może rozmawiała już wcześniej z mężczyzną, a może nawet z samym Bogiem - o tym autorzy Księgi nas nie informują. Być może chcieli tym samym dać do zrozumienia, że praca myślowa stała się najpierw udziałem kobiety i że to ona (nie jako rodzicielka, ale jako pierwszy homo sapiens) wprowadza gatunek ludzki w strefę człowieczeństwa. Dosłowne odczytanie tego fragmentu byłoby nawet z punktu widzenia teorii komunikacji wygodniejsze - wąż, chociaż mityczny, jako strona relacji komunikacyjnej wydaje się, paradoksalnie, kimś bardziej oczywistym, niż głos wewnętrzny - jednak żadną miarą nie możemy uwierzyć w pozametaforyczny status węża.

Dla kwestii antropogenezy ważne jest zakwestionowanie bezwzględnej determinacji przyrodniczej (tu występującej pod postacią wszechwładzy Boga), dla nauki o komunikacji natomiast ważna jest na przykład niewerbalna wymiana komunikatów między kobietą, wręczającą zerwany właśnie z drzewa wiadomości złego i dobrego owoc mężczyźnie, a mężczyzną, który owoc z jej ręki przyjął i zjadł. Nie kończy to całej serii zjawisk komunikacyjnych avant la lettre ${ }^{35}$, przeciwnie, mamy tu typowa rozmowę między ojcem i dzieckiem (pytanie „gdzie jesteś?”, chociaż ojciec wie, gdzie jest dziecko, niepewność dziecka, czy aby dobrze zrobiło, demonstrację wszechwiedzy - chociaż dopiero co Bóg udawał, że czegoś nie wie, tchórzliwe przerzucenie przez mężczyznę winy na kobietę

33 Przewrotność polega na tym, że ,upadkiem” nazwano to, co faktycznie jest powstaniem, wzniesieniem się, co jest obrazem antropogenezy, ukazaniem jej warunków i kryteriów.

34 Poprzednie to na przykład wydawanie poleceń samemu sobie („Niechaj zbiorą się wody...”, Rdz 1,9) pod pozorem wydawania ich „stworzeniu” czy „komunikaty”, adresowane przez formę („obraz Boga”) treści (mężczyźnie i kobiecie).

35 Tu: zanim ukształtował się kompletny zestaw typów podstawowych. 
i wreszcie nieco bardziej wyrafinowane przerzucenie przez kobietę winy na węża) oraz - last but not least - serię przekleństw rzuconych przez Nadawcę na odbiorców ${ }^{36}$. Odbiorcy milcząco przyjmują te komunikaty do wiadomości, szczęśliwie jednak przemiana następuje także w umyśle samego nadawcy, który, choć w klątwach bronił jeszcze swego statusu nadawcy absolutnego, przemawiającego do absolutnych odbiorców, odebrał i zrozumiał komunikat. A brzmiał on: oto odbiorca komunikatu stał się również nadawcą, komunikującym swój pogląd (swoją wolę, opinię itd.) dotychczasowemu absolutnemu nadawcy, pozbawiając tym samym tego ostatniego jego absolutnego statusu. Bóg nie tylko „sporządził dla mężczyzny i kobiety odzienie ze skór"37, ale przede wszystkim zaakceptował nową sytuację - w tym i nową sytuację komunikacyjną - uznając żądanie człowieka, by odtąd traktowano go nie tylko jak odbiorcę, ale również - jak nadawcę komunikatu. „Oto człowiek stał się taki jak My..." ${ }^{38}$, zna dobro i zło i podobnie jak ja jemu, tak i on mnie może odtąd komunikować swój pogląd w tej kwestii. Dotąd domagałem się od niego bezwzględnego posłuchu (,z drzewa poznania dobra i zła nie wolno ci jeść...”), ale od dziś będziemy się słuchać nawzajem - będziemy dla siebie nawzajem nadawcą i odbiorcą komunikatów. O ile dawniej byłem dla człowieka nadawcą absolutnym, on zaś dla mnie absolutnym odbiorca, o tyle teraz „człowiek stał się taki jak My”, więc możemy już się ze sobą p orozumiewać, możemy zawierać z sobą przymierza.

Odnotujmy w tym miejscu pewien brak precyzji, zawarty w określeniu „człowiek stał się taki jak My”. Cała opowieść traktuje o tym, jak zmienia się nie tylko status człowieka - odbiorcy boskich komunikatów, ale również status Boga - tych komunikatów nadawcy. Nie tylko człowiek nie jest już tym samym, kim był przed zerwaniem i spożyciem owocu, ale i Bóg nie jest tym, kim był, dopóki kobieta, a później także mężczyzna, nie zakwestionowali jego pretensji do absolutnego komunikowania. Człowiek, ściśle rzecz biorąc, nie stał się taki jak dawny Bóg („taki jak My”), nie stał się absolutnym nadawcą - obaj stali się równorzędnymi stronami relacji komunikacyjnej, komunikującymi sobie nawzajem swoje warunki. Stworzyli razem (człowiek, pomagając Bogu wyrzec się władzy absolutnej, Bóg człowiekowi, konstruując i przedstawiając mu koncepcję przymierza) nowy, rozwinięty typ relacji komunikacyjnej, złożonej już nie

\footnotetext{
$36 \mathrm{Rdz} 3,14-19$.

$37 \mathrm{Rdz} 3,21$.

$38 \mathrm{Rdz} 3,22$.
} 
tylko - jak w opowieści o zakazie spożywania - z nadawcy, komunikatu i odbiorcy (którego „nadawczość” sprowadza się do sygnalizowania zgody na oczekiwane zachowanie), ale przede wszystkim ze stron o podwójnym statusie, statusie nadawcy połączonym ze statusem odbiorcy. Tak więc od tej chwili Stary Testament proponuje nam (i proponuje do wyboru! ${ }^{39}$ ) dwa typy relacji komunikacyjnych: komunikacyjną relację panowania i posłuszeństwa i komunikacyjną relację przymierza, umowy, uzgodnienia, a jednocześnie dwa typy porządków komunikacyjnych jako porządków kulturowych i politycznych. Stary Testament pozostawia nam wprawdzie w tym względzie wybór, nie sposób jednak oprzeć się wrażeniu, że jego autorzy-redaktorzy komunikują nam jednocześnie swoją osobistą preferencję: w końcu Prawo, będące w pierwszym rzędzie treścią Księgi, ma swoje źródło w Przymierzu, w porozumieniu, w niehierarchicznej relacji komunikacyjnej, a nie w pierwotnym, opartym na sile, na przewadze, arbitralnym wyrazie woli "Stwórcy”.

Dziwi więc, że liczni teoretycy „komunikowania masowego”, działający w obrębie kultury, szczycącej się swoimi biblijnymi korzeniami, tak jednoznacznie sprowadzają komunikację do nadawania i odbierania komunikatów. Czyżby dali się uwieść ,jedynie słusznej”, oficjalnej, autorytarnej interpretacji zawartego w Starym Testamencie przekazu kulturowego $?^{40}$ A tymczasem, o czym była mowa wyżej, Stary Testament pokazuje coś dokładnie odwrotnego, niż jego oficjalna interpretacja: pokazuje dwa typy relacji komunikacyjnych, a jednocześnie sugeruje ich integralną definicję, która jednak nie redukuje relacji komunikacyjnej do transmisji, do jednostronnego przekazu, a przeciwnie, to jej dwustronny charakter uważa za immanentny, uważa za istotny ${ }^{41}$. W świetle immanentnie dwustron-

39 Tak jak proponuje do wyboru hierarchiczny i niehierarchiczny obraz człowieka (sugerując zresztą dość przejrzyście, że tylko ten drugi jest tożsamy z „obrazem Boga”); zarazem jest to również propozycja opisowa: ,istnieją realnie dwa typy relacji komunikacyjnej” (podobnie jak dwa typy relacji międzyludzkich, porządków kulturowych i politycznych).

40 Zgodnie $\mathrm{z}$ tą oficjalną interpretacją mamy do czynienia w Biblii, podobnie jak u T. Goban-Klasa, wyłącznie z transmisją komunikatu od Boga, najpierw komunikującego, że tylko on może rozstrzygać o dobru i złu (tak należy wnioskować z zakazu rozstrzygania tego przez człowieka), co zostaje następnie skonkretyzowane w nadaniu prawa („,dziesięciorga przykazań”) przez Boga ludziom za pośrednictwem Mojżesza (a nie ustanowieniu go przez Boga i ludzi, a tym mniej - przez samych ludzi - w drodze umowy-przymierza).

41 Ludzie jako równorzędne podmioty stworzone na obraz Boga, ,człowiek stał się taki jak My" czy koncepcja przymierza. 
nego charakteru komunikacji to, co wygląda na relację jednostronnego „nadawania” jest tylko politycznie i ideologicznie zredukowaną, a więc zredukowaną z użyciem siły, par excellence dwustronną relacją komunikacyjną. Odmawianie (skądinąd, z powyższych względów, niezbyt wymownemu) odbiorcy pełnowymiarowego statusu podmiotu komunikowania jest niczym innym, jak tylko niebezinteresownym podniesieniem empirycznego status quo do rangi tego, co nieuchronne. Jednak owa ,nieuchronność" nie ma charakteru konieczności metafizycznej, a tylko ograniczonej przez aktualny układ sił między podmiotami konieczności politycznej. Biblijna koncepcja przymierza, a w wersji nowożytnej - idea umowy społecznej jest dobitnie sformułowaną alternatywą takiego ideologicznie jednostronnego podejścia do kwestii definicji relacji komunikacyjnych i tym samym do wyodrębnienia dwóch podstawowych typów komunikacji: typu rozwiniętego, gdzie nadawca jest jednocześnie odbiorcą, a odbiorca - nadawcą, i zredukowanego w efekcie znacznej dysproporcji sił między stronami, jednostronnego nadawania, gdzie nadawca wys tę p u j e tylko jako nadawca, a odbiorca tylko jako odbiorca. Jednocześnie ani nadawca nie jest tu tylko nadawca, ani odbiorca tylko odbiorcą: nie tylko odbiorca zmuszony jest do udawania, że nie jest podmiotem komunikowania; również nadawca niechętnie, i tylko w wyjątkowych przypadkach, ujawnia swój status odbiorcy. W definicjach, których autorzy upierają się przy immanentnie jednostronnym charakterze komunikowania, ukryta jest przemoc. Definiujący, ale także ten, kto definicję akceptuje, ponosi za nią odpowiedzialność.

\section{Summary}

The author of the paper highlights that McQuail's typology of communication, which is most commonly applied in Polish science, and quoted as a whole by Tomasz Goban-Klas, among others, refers to levels of communication discerned by means of a quantitative criterion. In the author's opinion, however, a type cannot be solely by quantitative differences. Therefore, he suggests that two types of communicative relations be directly referred to: obedience and covenant, which can in his opinion, alread btered in the Old Testament. He identifies two fundamental types of communication on this basis: an advanced type, where the sender is simultaneously a recipient, and the recipient is a sender; and a reduced type where the sender is only a sender, and the recipient only a recipient, which is a result of a significant disproportion of power between the parties. 
